\title{
The Effect of Chayote Extract (Sechium edule) On Blood Pressure in Pregnant Women with Hypertension
}

\author{
Nur Alfi Fauziah'), Kamilah Hidajati²), Ariawan Soejoenoes²) \\ 1)Applied Midwifery, Graduate Program, School of Health Polytechnics, \\ Ministry of Health Semarang \\ 2)School of Health Polytechnics, Ministry of Health Semarang
}

\begin{abstract}
Background: Increased blood pressure of pregnant women during pregnancy is one of the high risks during pregnancy which can lead to preeclampsia, eclampsia to maternal and infant mortality. One of the treatments recommended by pregnant women is to consume foods containing potassium and flavonoids, namely squash. This study aimed to determine the effect of squash pumpkin on changes in blood pressure of hypertensive mothers in pregnancy in the health center in Semarang City area.

Subjects and Methods: This was an experimental study. The study was conducted at community health centers in Semarang, Central Java, from March to May 2018. A sample of 20 pregnant women who experienced hypertension in pregnancy was divided into two groups, control and treatment groups. The dependent variable was blood pressure. The independent variable was the extract of chayote. The data were analyzed by a multiple linear regression.

Results: There were differences in systolic blood pressure before and after the administration of squash extract $(\mathrm{p}<0.001)$. There are differences in Diastoleic blood pressure before and after the administration of squash extract $(\mathrm{p}<0.001)$.

Conclusion: Consuming chayote can make an effort to help lower blood pressure in pregnant women with hypertension.
\end{abstract}

Keywords: flavonoids, hypertension in pregnancy, potassium, squash, blood pressure.

\section{Correspondence:}

Nur Alfi Fauziah. Postgraduate Midwifery Program, School of Health Polytechnics. Jl. Tirto Agung, Pedalangan, Banyumanik, Semarang City, 50268, Central Java, Indonesia. Email: nuralfifauziah24@yahoo.com.

\section{BACKGROUND}

Hypertension (high blood pressure) in pregnancy is hypertension that occurs after 20 weeks of pregnancy, with blood pressure reaching 140/90 $\mathrm{mmHg}$ without proteinuria (Pisani et al. 2017; Nzelu et al. 2017; Cudihy and Lee 2009). Hypertension can occur before pregnancy and during pregnancy. There are 2 pregnancy hypertension disorders, namely gestational hypertension (GH) and preeclampsia (PE) (Roberts et al. 2017; Ogle and Korda 2015). Hypertension results in blood vessels experiencing vasoconstriction (constriction), resulting in reduced blood supply to the body's tissues, so that loss of nutrient and oxygen intake gradually results in the organ not functioning even death (Cudihy and Lee 2009). Hypertension in pregnancy can also progress to mild preeclampsia and eventually increase to severe preeclampsia followed by subjective complaints of headache, epigastria pain, blurred vision, nausea, vomiting, and disturbance of consciousness (Nugroho, 2012).

Preeclampsia often occurs suddenly, it is necessary to detect it as early as possible during pregnancy. Early detection is done 
by routine blood pressure checks at the time of pregnancy examination. Pregnancy checks are routinely carried out so that the risk of preeclampsia can be detected immediately so that no more fatal complications occur (Rukiyah, 2012).

Hypertension is the second cause of maternal death, which occurs in $5-10 \%$ of all pregnancies (Malik, 2016; Vest and Cho 2014). The causes of death of pregnant women include bleeding (25\%), hypertension $(12 \%)$, congestion $(8 \%)$, abortion $(13 \%)$ and other causes (7\%)(World Health Organization 2013). According to WHO (World Health Organization) data in 2013 cardiovascular disease accounted for around $17 \mathrm{mi}$ llion deaths per year, almost one third of the total population. Of these, hypertension complications reached 9.4 million deaths worldwide every year. Hypertension is responsible for at least $45 \%$ of deaths from heart disease(World Health Organization 2013).

Data from the Central Java Provincial Health Office in 2015 the highest cases of maternal mortality due to hypertension as much as $26.34 \%$ and bleeding as much as $21.14 \%$. The number of maternal deaths in 2016 was 32 cases with a number of live births of 26,337 cases or 121.5 per 100,000 live births (Health Service Offices of Central Java Province, 2015). Data from the Semarang District Health Office in 2015, because preeclampsia was $34 \%$ and bleeding was 28\%. Whereas in 2016 due to preeclampsia as much as $21 \%$ and as much as $12 \%$ (Health Service Offices of Semarang City, 2016).

Handling of hypertension cases in pregnant women has been carried out by giving anti-hypertensive drugs. Treatment of hypertension to date is non-pharmacological (herbal) and pharmacological therapy. No pharmacological therapy is a complement to pharmacological therapy to get a better treatment effect(Dalimartha, 2008).
Non-pharmacological therapy (herbal) has various benefits for those who consume it, including more affordable prices, easily obtained, does not cause side effects, increase endurance because it contains many vitamins that are useful for health. Taking herbs has been done by our ancestors in ancient times (Pereira et al., 2016). After science develops, research on herbs that can cure various diseases is carried out. It turns out that herbs contain substances that can cure disease(Nisa, 2012)

Non-pharmacological (herbal) treatment of hypertension, including fruits, vegetables, leaves, and roots containing potassium, calcium and other important substances. Patients with hypertension are generally deficient in potassium and calcium which is the right way to reduce blood pressure, one of which is chayote (Sechium edule) (Luh et al, 2012; Nisa, 2012; Jayani, 2016).

Siam squash (Sechium edule) is efficacious as an antipyretic, anti-inflammatory and contains potassium so it can lower blood pressure (Lombardo-earl et al, 2014). Conjoined squash (Sechium edule) is easily available, at an affordable price, and there are no side effects. Besides folic acid, chayote also contains potassium, energy, protein, fat, carbohydrates, fiber, sugar, calcium, zinc, copper, manganese, selenium, vitamin $\mathrm{C}$, thiamine, riboflavin, niacin, vitamin $\mathrm{B} 6$, and vitamin E. Vitamin K very beneficial for the body (Tjoawirawan, 2012; Luh et al., 2012)

Yanti's study on 2017 reported that there was an influence between squash squeeze to decrease blood pressure in hypertensive patients with an average reduction in systolic blood pressure of $15.50 \mathrm{mmHg}$ and Diastoleic 9.0 mmHg (Yanti, 2017). A study by Nadila in 2014 reported that one of the plants used as antihypertensive was chayote fruit (Sechium edule). The active compound in the squash fruit that fun- 
ctions as an antihypertensive is flavonoids, saponins, and alkaloids that can inhibit angiotensin I converting enzyme (ACE) and as a diuretic.

The use of chayote is usually consumed in the form of steamed or juice and juice, extracts can now be made in capsule form according to certain concentrations and procedures. In addition to being more practical, the use of chayote extract in capsule form can also be stored for a longer period than consumed in the form of steamed or juice(Paramawati, 2016). For that use chayote as a treatment with natural ingredients that are economical and have minimal negative effects to be a good solution to overcome health problems, especially hypertension. Based on the description, the researcher was interested in conducting research entitled "Effect of blood pressure reduction on hypertensive mothers in pregnancy with squash extract (Sechium edule)".

\section{$\frac{\text { SUBJECTS AND METHOD }}{\text { 1. Study Design }}$}

This was a quasy-experimental study with the design of Non eqiuvalent control group design. The study was conducted at the Semarang City Community Health Center (Tlogosari Wetan Health Center, Tlogosari Kulon Health Center, Bangetayu Health Center and Srondol Health Center) from March to May 2018.

\section{Population and sample}

The population in this study were pregnant women who experienced hypertension in pregnancy at the Semarang City Health Center on March to May 2018. Samples of 20 pregnant women with sampling according to inclusion criteria.

\section{Study Variables}

The dependent variable was blood pressure. The independent variable was the extract of chayote.

\section{Operational Definition of Variables} Pumpkin extract made into powder and then put into capsules and given to respondents (treatment) $1 \times 500 \mathrm{mg}$ for 11 days after 2 hours of antihypertensive drug administration.

\section{Study Instruments}

The data collected by observation sheet. The measurement scale is categorical. Blood pressure is the value of systolic and Diastoleic blood pressure that changes after the intervention after 2 hours of giving the pumpkin extract. Data collected with observation sheets and digital sphygmomanometer. The measurement scale is numerical.

\section{Data analysis}

Univariate analysis was carried out to see the frequency distribution and characteristics of the study subjects, while the bivariate analysis was carried out using the general linear model repeated measure test because the measurement was more than twice and Post Hoc to see differences in blood pressure before and after intervention in one group and between groups research.

\section{Research Ethics}

Research ethics including informed consent, anonymity, confidentiality, and ethical permission. Ethical permits in this study were conducted at the Semarang Health Ministry Polytechnic and declared ethically feasible based on the decision letter number: 131/KEPK / Poltekkes-Smg/EC/2018.

\begin{tabular}{l} 
RESULTS \\
\hline 1. Sample Characteristics \\
Distribution of the characteristics of resp- \\
ondents in this study included the age, pa- \\
rity, past pregnancy / childbirth / childbir- \\
th history and family history that will be \\
explained in table 1.
\end{tabular}


Table 1. Sample Characteristics

\begin{tabular}{|c|c|c|c|c|c|c|c|}
\hline \multirow[t]{2}{*}{ Characteristics } & \multicolumn{2}{|c|}{$\begin{array}{c}\text { Control group } \\
(n=10)\end{array}$} & \multicolumn{2}{|c|}{$\begin{array}{c}\text { Treatment } \\
\text { group }(n=10)\end{array}$} & \multicolumn{2}{|c|}{ Total } & \multirow[t]{2}{*}{$\mathbf{p}$} \\
\hline & $\mathbf{N}$ & $\%$ & $\mathbf{N}$ & $\%$ & $\mathbf{N}$ & $\%$ & \\
\hline Age $($ mean \pm SD $)$ & \multicolumn{2}{|c|}{$34 \cdot 30 \pm 3 \cdot 71$} & \multicolumn{2}{|c|}{$34.40 \pm 4.12$} & \multicolumn{2}{|c|}{$34.35 \pm 3.82$} & \\
\hline Min-Max & \multicolumn{2}{|c|}{$27-41$} & \multicolumn{2}{|c|}{$29-42$} & \multicolumn{2}{|c|}{$27-42$} & \\
\hline$<20$ year & - & - & - & - & - & - & 0.548 \\
\hline 20-35 year & 5 & 50 & 6 & 60 & 11 & 55 & \\
\hline > 35 year & 5 & 50 & 4 & 40 & 9 & 45 & \\
\hline \multicolumn{8}{|l|}{ Parity } \\
\hline Primipara & 5 & 50 & 1 & 10 & 6 & 30 & \multirow{3}{*}{1.000} \\
\hline Multipara & 4 & 40 & 4 & 40 & 8 & 40 & \\
\hline Grandemultipara & 1 & 10 & 5 & 50 & 6 & 30 & \\
\hline \multicolumn{8}{|c|}{ Past Pregnancy / Childbirth / Postpartum History } \\
\hline No & 3 & 80 & 5 & 50 & 8 & 35 & \multirow[t]{2}{*}{0.207} \\
\hline Yes & 7 & 20 & 5 & 50 & 12 & 65 & \\
\hline \multicolumn{8}{|l|}{ Family History } \\
\hline No & 8 & 80 & 9 & 90 & 17 & 85 & \multirow[t]{2}{*}{0.232} \\
\hline Yes & 2 & 20 & 1 & 10 & 3 & 15 & \\
\hline
\end{tabular}

2. Univariate Analysis

The results of measurements of systolic and Diastoleic blood pressure values before and after the administration of antihypertensive drugs are shown in Table 2.

Table 2. Measurement of systolic and Diastoleic blood pressure values in the control group (antihypertensive drugs)

\begin{tabular}{lcccc}
\hline \multicolumn{1}{c}{ Control group } & Minimum value & Maximum value & Mean & SD \\
\hline Systolic & & & & \\
Pre Systole & 145 & 158 & 151.40 & 3.92 \\
Post Systole 1 & 145 & 154 & 148.80 & 2.66 \\
Post Systole 3 & 142 & 170 & 150.60 & 7.73 \\
Post Systole 5 & 136 & 165 & 151.00 & 7.60 \\
Post Systole 7 & 142 & 163 & 150.80 & 5.33 \\
Post Systole 9 & 146 & 158 & 151.70 & 4.27 \\
Post Systole 11 & 140 & 159 & 148.80 & 5.11 \\
Diastolic & & & & \\
Pre Diastole & 92 & 110 & 100.40 & 5.40 \\
Post Diastole 1 & 95 & 109 & 99.90 & 4.04 \\
Post Diastole 3 & 93 & 110 & 99.40 & 4.57 \\
Post Diastole 5 & 90 & 107 & 98.00 & 5.18 \\
Post Diastole 7 & 90 & 105 & 95.80 & 4.26 \\
Post Diastole 9 & 90 & 103 & 95.40 & 4.67 \\
Post Diastole 11 & 85 & 102 & 94.30 & 5.58 \\
\hline
\end{tabular}

From table 2 above, it is explained that from all measurements of systolic and Diastolic blood pressure in the control group, there was a decrease in each measurement.
Changes in the average measurement of systolic blood pressure in the treatment and control groups measured every two days for 11 days can be seen in the graph below: 


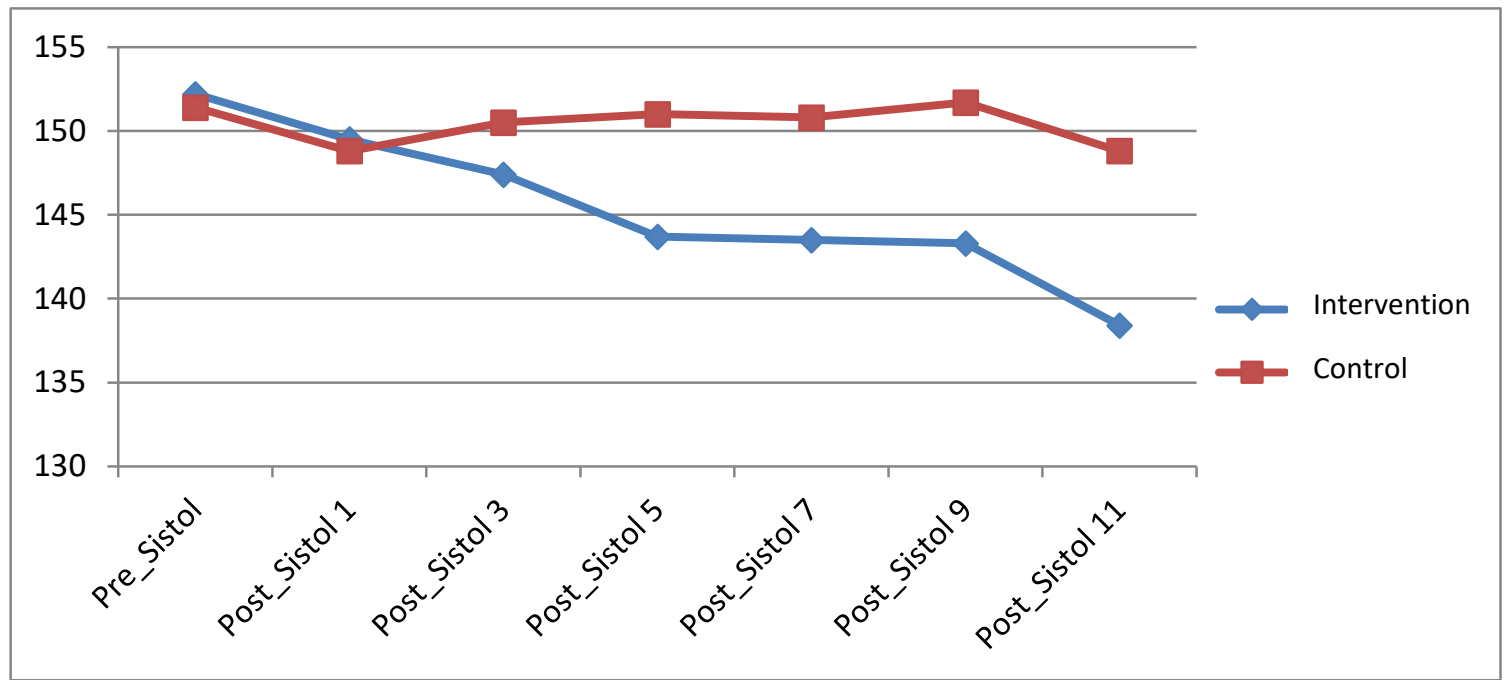

Figure 1. Changes in the mean systolic blood pressure in the treatment and control groups

Figure 1 above shows that the average change in systolic blood pressure on the first day to the 11th day for the treatment group and control group with an average value decreased. It can be concluded that blood pressure in the treatment group was better than the control group.

Table 3. Measurement of systolic and Diastolic blood pressure values in the treatment group (antihypertensive drugs and chayote extracts)

\begin{tabular}{lcccc}
\hline Treatment group & Minimum value & Maximum value & Mean & $\begin{array}{c}\text { Standard } \\
\text { deviation }\end{array}$ \\
\hline Systolic & & & & \\
Pre Systole & 140 & 171 & 152.20 & 9.57 \\
Post Systole 1 & 140 & 160 & 149.50 & 7.50 \\
Post Systole 3 & 136 & 162 & 147.40 & 8.58 \\
Post Systole 5 & 135 & 159 & 143.70 & 8.26 \\
Post Systole 7 & 134 & 155 & 143.50 & 6.15 \\
Post Systole 9 & 127 & 157 & 143.30 & 8.55 \\
Post Systole 11 & 128 & 150 & 138.40 & 7.63 \\
Diastolic & & & & \\
Pre Diastole & 98 & 107 & 102.30 & 2.83 \\
Post Diastole 1 & 99 & 107 & 101.70 & 2.91 \\
Post Diastole 3 & 97 & 102 & 99.30 & 1.77 \\
Post Diastole 5 & 90 & 105 & 96.80 & 4.98 \\
Post Diastole 7 & 88 & 103 & 93.30 & 4.71 \\
Post Diastole 9 & 85 & 102 & 91.70 & 6.18 \\
Post Diastole 11 & 83 & 99 & 91.10 & 4.82 \\
\hline
\end{tabular}

The results of measurements of systolic and diastolic blood pressure values before and after the administration of antihypertensive drugs and chayote extracts are shown in Table 3. 
From table 3 above, it is explained that from all measurements of systolic and Diastolic blood pressure in the treatment group, there was a decrease in each measurement.
Changes in the average measurement of Diastolic blood pressure in the treatment and control groups which were measured every two days for 11 days can be seen in the graph below:

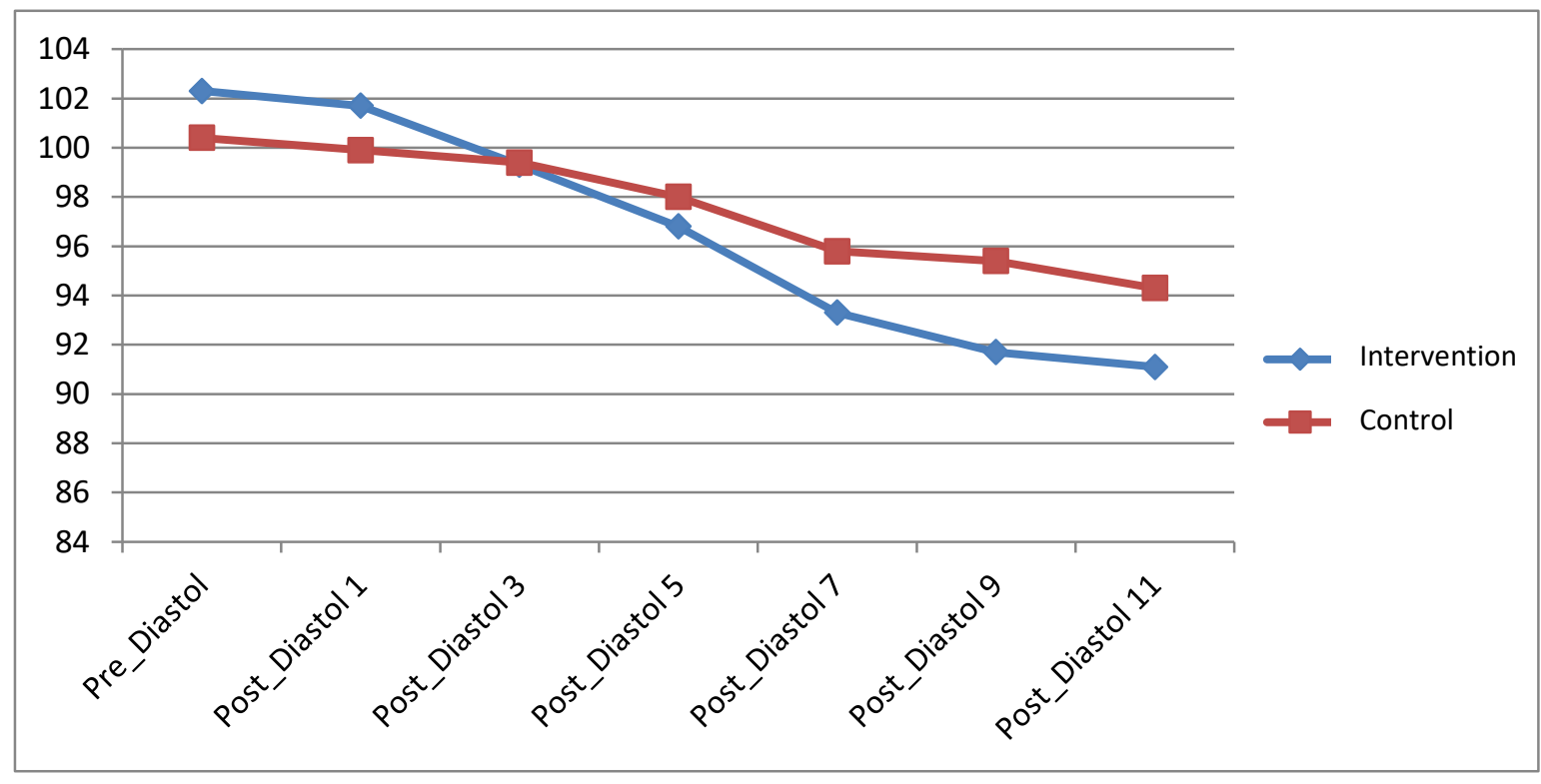

Figure 2. Changes in the mean diastolic blood pressure in the treatment and control groups

Figure 2 above shows that the change in the average diastolic blood pressure on the first day to the 11th day for the treatment group and control group with an average value decreased. It can be concluded that blood pr- essure in the treatment group was better than the control group.

\section{Bivariate analysis}

Analysis of Differences in Systolic Pressure in the Treatment and Control Groups

Table 4. Differences in Systolic blood pressure in the treatment group and control group.

\begin{tabular}{cccccc}
\hline Source & Type III Sum of Squares & df & Mean Square & F & P value \\
\hline TD systole & 3037326.01 & 1 & 3037326.01 & $1.348 \mathrm{E} 4$ & $<0.001$ \\
\hline
\end{tabular}

The Repeated Measure ANOVA (Test of Between-Subjects Effect) analysis in table 4 shows that the $\mathrm{p}$ value $<0.05$ which means that there is a significant difference between systolic blood pressure in the treatment group and the control group.

Analysis of Differences in Systolic blood pressure before and after treatment groups and control groups 
Indonesian Journal of Medicine (2019), 4(3): 266-277

https://doi.org/10.26911/theijmed.2019.04.03.10

Table 5. Differences in Systolic Blood Pressure Levels Before and After Treatment Groups and Control Groups

\begin{tabular}{lccccccc}
\hline \multicolumn{2}{c}{ Control group } & \multicolumn{4}{c}{ Treatment group } \\
\hline \multicolumn{2}{c}{ Systolic } & $\begin{array}{c}\text { Mean } \\
\text { Difference }\end{array}$ & $\mathbf{p}$ & & Systolic & $\begin{array}{c}\text { Mean } \\
\text { Difference }\end{array}$ & p \\
\hline Pre & Post 11 & 2.60 & 1.000 & Pre & Post 11 & 18.00 & $<0.001$ \\
Pre & Post 1 & 2.60 & 0.757 & Pre & Post 1 & 2.70 & 0.440 \\
Post 1 & Post 3 & -1.80 & 1.000 & Post 1 & Post 3 & 1.20 & 1.000 \\
Post 3 & Post 5 & -0.40 & 1.000 & Post 3 & Post 5 & 4.70 & 0.043 \\
Post 5 & Post 7 & 0.20 & 1.000 & Post 5 & Post 7 & 1.60 & 1.000 \\
Post 7 & Post 9 & -0.90 & 1.000 & Post 7 & Post 9 & 2.80 & 0.366 \\
Post 9 & Post 11 & 2.90 & 1.000 & Post 9 & Post 11 & 5.00 & 0.002 \\
\hline
\end{tabular}

The results of Test of Within-Subjects Effect obtained the value of $[\mathrm{F}(4.13,74.41)=$ 14.32]; $\mathrm{p}<0.001$. Table 5 illustrates the results of the post hoc paires wise comparison test meaning that there are differences in Table 6. Differences in systolic blood pressure between treatment and control groups

\begin{tabular}{|c|c|c|c|}
\hline \multicolumn{3}{|c|}{ Variable } & \multirow[b]{2}{*}{$\mathbf{p}$} \\
\hline Systolic blood pressure & Group & $\operatorname{Mean} \pm$ SD & \\
\hline \multirow[t]{2}{*}{ Pre } & Control & $151.40 \pm 3.92$ & \multirow{2}{*}{0.809} \\
\hline & Treatment & $152.20 \pm 9.57$ & \\
\hline \multirow[t]{2}{*}{ Post 1} & Control & $148.80 \pm 2.66$ & \multirow{2}{*}{0.784} \\
\hline & Treatment & $149.50 \pm 7.50$ & \\
\hline \multirow[t]{2}{*}{ Post 3} & Control & $150.60 \pm 7.73$ & \multirow{2}{*}{0.531} \\
\hline & Treatment & $147.40 \pm 8.58$ & \\
\hline \multirow[t]{2}{*}{ Post 5} & Control & $151.00 \pm 7.60$ & \multirow{2}{*}{0.041} \\
\hline & Treatment & $143.70 \pm 8.26$ & \\
\hline \multirow[t]{2}{*}{ Post 7} & Control & $150.80 \pm 5 \cdot 33$ & \multirow{2}{*}{0.006} \\
\hline & Treatment & $143.50 \pm 6.15$ & \\
\hline \multirow[t]{2}{*}{ Post 9} & Control & $151.70 \pm 4.27$ & \multirow{2}{*}{$<0.001$} \\
\hline & Treatment & $143.30 \pm 8.55$ & \\
\hline \multirow[t]{2}{*}{ Post 11} & Control & $148.80 \pm 5.12$ & \multirow{2}{*}{$<0.001$} \\
\hline & Treatment & $138.40 \pm 7.63$ & \\
\hline
\end{tabular}

In table 6 the results of the reapeted measure showed the results of systolic measurements from pretest to posttest 11 for each group showed $\mathrm{p}$ value in measurement 5 systolic blood pressure in each treatment group and control group. Analysis of differences in systolic blood pressure between the treatment group and the control group 
Fauziah et al./ The effect of chayote extract on blood pressure

Table 7. Differences in diastolic blood pressure in the treatment and control groups

\begin{tabular}{cccccc}
\hline Source & Type III Sum of Squares & df & Mean Square & F & P value \\
\hline TD Diastole & 1318618.35 & 1 & 1318618.35 & $1.196 \mathrm{E} 4$ & $<0.001$ \\
\hline
\end{tabular}

The Repeated Measure ANOVA (Test of Between-Subjects Effect) analysis in table 7 shows that the $\mathrm{p}$ value $<0.05$ which means that there is a significant difference between diastolic blood pressure in the treatment group and the control group.

Table 8. Differences in the value of diastolic blood pressure before and after treatment groups and control groups

\begin{tabular}{lccclccc}
\hline \multicolumn{3}{c}{ Control group } & \multicolumn{4}{c}{ Treatment group } \\
\hline \multicolumn{2}{c}{ Systolic } & $\begin{array}{c}\text { Mean } \\
\text { Difference }\end{array}$ & $\mathbf{p}$ & & Systolic & $\begin{array}{c}\text { Mean } \\
\text { Difference }\end{array}$ & p \\
\hline Pre & Post 11 & 6.10 & 0.017 & Pre & Post 11 & 11.90 & 0.006 \\
Pre & Post 1 & 0.50 & 1.000 & Pre & Post 1 & 0.60 & 1.000 \\
Post 1 & Post 3 & 0.50 & 1.000 & Post 1 & Post 3 & 2.40 & 0.352 \\
Post 3 & Post 5 & 1.40 & 1.000 & Post 3 & Post 5 & 2.50 & 1.000 \\
Post 5 & Post 7 & 2.20 & 0.366 & Post 5 & Post 7 & 3.50 & 0.352 \\
Post 7 & Post 9 & 0.40 & 1.000 & Post 7 & Post 9 & 1.60 & 1.000 \\
Post 9 & Post 11 & 1.10 & 1.000 & Post 9 & Post 11 & 1.30 & 1.000 \\
\hline
\end{tabular}

The results of Test of Within-Subjects Effect obtained the value of $[\mathrm{F}(3.334,60.005)$ $=4.28] ; \mathrm{p}=0.008$. Table 8 illustrates the results of the post hoc paires wise

Table 9. Differences in Diastoleic blood pressure between treatment and control groups

\begin{tabular}{|c|c|c|c|}
\hline \multicolumn{3}{|c|}{ Variable } & \multirow[b]{2}{*}{$\mathbf{p}$} \\
\hline Systolic blood pressure & Group & $\operatorname{Mean} \pm$ SD & \\
\hline \multirow[t]{2}{*}{ Pre } & Control & $100.40 \pm 5.40$ & \multirow[b]{2}{*}{0.337} \\
\hline & Treatment & $102.30 \pm 2.83$ & \\
\hline \multirow[t]{2}{*}{ Post 1} & Control & $99.90 \pm 4.04$ & \multirow{2}{*}{0.268} \\
\hline & Treatment & $101.70 \pm 2.91$ & \\
\hline \multirow[t]{2}{*}{ Post 3} & Control & $99.40 \pm 4.57$ & \multirow[b]{2}{*}{0.949} \\
\hline & Treatment & $99.30 \pm 1.77$ & \\
\hline \multirow{2}{*}{ Post 5} & Control & $98.00 \pm 5.18$ & \multirow[b]{2}{*}{0.604} \\
\hline & Treatment & $96.80 \pm 4.98$ & \\
\hline \multirow[t]{2}{*}{ Post 7} & Control & $95.80 \pm 4.26$ & \multirow{2}{*}{0.230} \\
\hline & Treatment & $93 \cdot 30 \pm 4.71$ & \\
\hline \multirow[t]{2}{*}{ Post 9} & Control & $95.40 \pm 4.67$ & \multirow{2}{*}{0.148} \\
\hline & Treatment & $91.70 \pm 6.18$ & \\
\hline \multirow[t]{2}{*}{ Post 11} & Control & $94.30 \pm 5.58$ & \multirow[b]{2}{*}{0.141} \\
\hline & Treatment & $91.10 \pm 4.82$ & \\
\hline
\end{tabular}

In table 4.10 the results of the repeated measure showed the results of diastolic measurements from pretest to posttest 11 for ea- comparison test meaning that there are differences in diastolic blood pressure in each treatment group and control group. 
en the treatment group and the control group both experienced decrease.

\begin{tabular}{l}
\hline DISCUSSION \\
\hline Blood pressure is the amount of force given \\
by blood in the interior of the artery when \\
blood is pumped throughout the circulatory \\
system. Every time the heart muscle contra- \\
cts, blood is pressed against the blood vess- \\
el wall and calculated as systolic blood pres- \\
sure. When the heart relaxes between pul- \\
ses, the pressure on the blood vessel wall is \\
calculated as diastolic blood pressure \\
(Hernawati,2011).
\end{tabular}

Siam squash is efficacious as antipyretic, anti-inflammatory and lowers high blood pressure. Siam squash is easy to get, at an affordable price, and there are no side effects. Chayote is good for pregnant women because it has a high amount of folic acid (Nisa, 2012).

Siamese Pumpkin fruit is rich in potassium, potassium is useful for the body to control blood pressure, as a high blood therapy, and cleanse carbon dioxide in the blood. Potassium is also useful to trigger the work of muscles and nerve nodes. High potassium will facilitate the delivery of oxygen to the brain and help maintain fluid balance, so the body becomes fresher. Patients with high blood pressure are recommended to consume squash regularly (Nisa, 2012).

Based on the results of this study showed that the administration of squash extract (Sechium edule) was proven to affect the decrease of systolic and diastolic blood pressure after being given $500 \mathrm{mg} /$ day for 11 consecutive days in pregnant women with hypertension in pregnancy.

In statistical tests using Repeated Measure Generalized Linear Model (GLM) at systolic blood pressure showed that there was a difference between systolic blood pressure in the control group and the intervention group $(p=0.023)$ and in the statistical test diastolic blood pressure showed that there was a difference between pressure diastolic blood in the control group and intervention group $(\mathrm{p}=0.021)$.

Several studies are in line with the results of this study, namely the results of Dire's (2007) study that cloak has antihypertensive effects, according to Djaelani (2012), he found differences in systolic and diastolic pressure before and after the administration of chayote. Without medication, the blood pressure of hypertensive patients falls after consuming squash for five consecutive days. This occurs because chayote contains high potassium, and other compounds such as alkaloids and flavonoids (Hakim, 2015; Djaelani, 2015)

A study by Yuninda (2009) reported the effect of Sechium edule juice on blood pressure of adult women. The data measured were systolic and diastolic blood pressure for 3 days. The average results of systolic blood pressure on the first, second and third days after drinking squash juice decreased by $12.66 \mathrm{mmHg}, 9.53 \mathrm{mmHg}$ and 7.27 $\mathrm{mmHg}$ compared to before drinking chayote juice. While the average results of diastolic blood pressure on the first, second and third days after drinking squash juice decreased by $5.66 \mathrm{mmHg}, 3.4 \mathrm{mmHg}$ and $2.99 \mathrm{mmHg}$ compared to before drinking chayote juice (Yuninda, 2009).

Hypertension that occurs in pregnancy is caused by a decrease in blood flow and uterine perfusion that stimulates excessive release of renin, this causes the renin released to flow along with the blood to the liver and react with angiotensinogen to convert angiotensin I to angiotensin II which when accumulated with thromboxane will cause vasoplasm which causes the anteriol lumen to narrow and the anteriol pressure increase. In addition angiotensin II also stimulates the adrenal cortex to produce the hormone aldosetrol which causes sodium 
retention and raises blood volume and pressure (Kowalak, 2011)

To inhibit the formation of angiotensin II, flavonoids which are bioactive compounds with high antioxidants are needed, work directly on smooth muscle by activating endothelium derived relaxing factor (EDRF), causing vasodilation and inhibiting angiotensin-converting enzyme (ACE) so that angiotensin I cannot be converted to angiotensin II. Anthocyanin which are the most abundant compounds in flavonoids will accumulate into endothelial cells and protect from free radicals, so they can maintain Nitric Oxide Synthase (NOS) as a strong vasodilator (Won et al., 2010; June et al., 2018).

Reduction in blood pressure during pregnancy can also be affected by the production of the hormone progesterone. This hormone affects the muscles to become more relaxed. Then affecting the blood vessels tends to widen/vasodilation. This blood vessel dilation makes blood pressure decrease.

\section{AUTHOR CONTRIBUTIONS}

Nur Alfi Fauziah selected the study subjects, collected the data, measured quality of sleep, and wrote the manuscript. Kamilah Hidajati gave theoretical suggestion the effect of chayote extract on hypertension. Ariawan Soejoenoes did the data analysis and interpreted the results of data analysis.

\section{CONFLICT OF INTEREST}

We declare that we do not have any conflict of interest.

\section{FUNDING AND SPONSORSHIP}

There is no external fund and sponsorship.

\section{ACKNOWLEDGEMENT}

We would like to thank Central Java Provincial Health Office for giving permission to collect the data. Thanks to the study subjects in Gedawang, Banyumanik, Semarang, Central Java, who participated in this study.

\section{REFERENCE}

$\overline{\text { Rukiyah AI LY (2012). Asuhan Kebidanan }}$ Patologi Kebidanan, Jakarta: Trans Info Media.

Cudihy D, Lee RV (2009). The pathophysiology of pre-eclampsia : Current clinical concepts. 2: 576-582.

Dalimartha S, Purnama BT, Sutarina N, Mahendra B, Darmawan R (2008). Care Your Self Hipertensi, Jakarta: Penebar Plus.

Djaelani EKP (2015). Pengaruh Sari Buah Labu Siam Terhadap Perubahan Tekanan Darah Pada Lansia Penderita Hipertensi.

Etri Yanti RIS (2017). Pengaruh Pemberian Perasan Labu Siam (Secium Edule) terhadap Tekanan Darah pada Penderita Hipertensi. Jurnal Kesehatan Medika Saintika, 8(1).

Hernawati (2011). Sistem Renin-Angiotensin-Aldosteron: Perannya Dalam Pengaturan Tekanan Darah dan Hipertensi,

Nisa I (2012). Ajaibnya terapi herbal tumpas penyakit darah tinggi, Jakarta: Dunia Sehat.

Jayani I (2016). Pemberian Labu Siam Berimplikasi Terhadap Perubahan Tekanan Darah Ibu Hamil Preeklampsi., 4(2).

Erdman JW Jr, Balentine D, Arab L, Beecher G, Dwyer JT, Folts J, Harnly J, Hollman P, et al. (2018). Flavonoids and Heart Health : Proceedings of the ILSI North America Flavonoids Work- 
shop, J Nutr. 137(1): 718S-737S. doi: 10.1093/jn/137.3.718S.

Health Service Offices of Semarang City, (2016). Profil Kesehatan Kota Semarang.

Health Service Offices of Central Java Province (2015). Profil Kesehatan Provinsi Jawa Tengah.

Kowalak (2011). Buku Ajar Patofisiologi, Jakarta : EGC.

Lombardo-Earl G, Roman-Ramos R, Zamilpa A, Herrera-Ruiz M, Rosas-Salgado $\mathrm{G}$, Tortoriello $\mathrm{J}$, and Jiménez-Ferrer E(2014). Extracts and Fractions from Edible Roots of Sechium edule (Jacq) $\mathrm{Sw}$ with Antihypertensive Activity. Evidence-Based Complementary and Alternative Medicine. 1-9. doi: 10.1155/2014/594359

Luh N, Fitriani C, Walanda DK (2012). Determination of Potassium (K) and Calcium (Ca) Content in Chayote (Sechium edule) and The Effects With its Growth Soil. 1: 174-180.

Hakim L (2015). Optimasi Dosis Aplikasi Farmakokinetik dalam Penemuan Obat dan Pengobatan, Bursa Ilmu.

Nadila F (2014). Antihypertensive Potential Of Chayote Fruit Extract Kandungan Labu Siam Potensi Flavonoid, 3: 3438.

Nisa I (2013). Khasiat Sakti Tanaman Obat Untuk Darah Tinggi Cetakan 1, Jakarta: Dunia Sehat.

Nzelu D, Dumitrascu B, Hunt KF, Cordina M, Kametas NA (2017). Pregnancy outcomes in women with previous gestational hypertension: A cohort study to guide counselling and management. Pregnancy Hypertension. doi: 10.1016/j.preghy.2017.10.011.

Ogle R, Korda A (2015). Hypertension in pregnancy and long term cardiovascular mortality: a retrospective cohort study. American Journal of Obstetrics and Gynecology, (2016). doi: 10.1016/j.ajog.2015.12.047.

Pisani I, Tiralongo GM, Lo Presti D, Gagliardi G, Farsetti D, Vasapollo B3, Novelli GP, Andreoli A, Valensise H, (2017). Correlation between Maternal Body Composition and Haemodynamic Changes in Pregnancy: Different Profiles for Different Hypertensive Disorders. Pregnancy Hypertension: An International Journal of Women's Cardiovascular Health. doi: 10.1016/j.preghy.2017.07.149.

Paramawati RHDRD (2016). Khasiat Ajaib Daun Advokat, Jakarta: Penebar swadaya.

Roberts LM,Davis GK, Homer CS (2017). Pregnancy with gestational hypertension or preeclampsia: A qualitative exploration of women's experiences. Midwifery, 46: 17-23. doi: 10.1016/j.midw.2017.01.004.

Pereira ARA, Velho APM, Cortez DAG, Szerwieski LLD, Cortez LER (2016). Traditional use of medicinal plants by elderly. Revista da Rede de Enfermagem do Nordeste, 17(3).

Malik VKR (2016). Hypertension in Pregnancy. Springer International Publishing Switzerland.

Nugroho T (2012). Patologi Kebidanan Cetakan 2, Yogyakarta: Nuha Medika.

Tjoawirawan NB (2012). The Effect of Chayote (Sechium edule Swartz) On Blood Pressure.

Vest AR, Cho LS (2014). Hypertension in Pregnancy. Springer Science. doi: 10.10 07/s11883-013-0395-8.

Kwon EK, Lee DY, Lee H, Kim DO, Baek NI, Kim YE, Kim HY (2010). Flavonoids From The Buds Of Rosa Damascena Inhibit The Activity Of 3-Hydroxy3-Methylglutaryl-Coenzyme A Reductase and Angiotensin I-Converting Enzyme. 882-886. 
Fauziah et al./ The effect of chayote extract on blood pressure

World Health Organization (2013). A Yuninda E (2009). The Effect Of Labu Siam Global Brief on Hypertension. Juice (Sechium edule) On Female Blood Presure 